\title{
No Smoking in the European Parliament: Issue Saliency and Policy Preferences of Euro-parliamentarians
}

Jun, Hae-Won

(Sogang University)

$\langle$ CONTENTS〉

I. Introduction

II. Policy-seeking by Amendment

III. Hypotheses
IV. Statistical Analysis

1. Variables

2. Results

V. Conclusion

- Keywords: Tobacco control, European Union, European Parliament, roll call voting

\section{【ABSTRACT】}

This article examines the formation of policy preferences through the lens of issue saliency in the European Parliament. When legislators pursue policy preferences, they select some issues from a range of interests they are supposed to represent. The choice depends on two factors: policy question's saliency to those interests and the compatibility between those interests and legislators' ideologies and constituents' interests. This is tested with roll call votes on the 2001 Tobacco Products Directive. Euro-parliamentarians' policy positions are based on the positions of member states, national parties, and interest groups including the tobacco industry and health groups. The main finding is that their policy preferences are formed not only with partisanship based on the left-right ideology and EU integration but also based on nationality. In the case of tobacco regulation, parliamentarians are driven more by national culture and lobbies from sectoral interests than by public health concern. 


\section{I . Introduction}

The formation of a legislator's policy position is an essential question in studies of 'substantive' representation that examine policy responsiveness in parliamentarians' legislative behavior. ${ }^{1)}$ These sorts of projects ask how legislators reconcile conflicting interests in order to take a particular policy position and decide how to cast their votes. Parliamentarians are frequently faced with the need to make two kinds of choices: a choice between public interests and special interests and one between different special interests. In the first case, normatively the legislators should make a publicly beneficial policy regardless of the interests they represent. The reality, however, shows that policies compromising public interests are frequently promoted by the legislators even in the most democratic governments. This begs the question of how the legislators form their policy positions when the public interests collide with the private interests. And then there is the second choice: where legislators must choose between multiple special interests including constituencies' interests. Legislators receive a mandate from their electorates and are obliged to promote their interests. The problem is that the interests of the electorates are not fixed, with multiple interests conflicting within a constituency. Knowing which among those interests the legislators choose to represent is crucial to assessing their accountability in policy making.

The literature, however, generally investigates the formation of legislators' policy preferences in legislative voting to a limited extent. Most roll call vote analyses focuses on the impact of legislators' ideologies, constituency interests and different institutional factors like electoral systems on voting. ${ }^{2}$ Whereas those studies explain the shape of legislative coalitions well, they do not explain how these coalitions are related to legislators' choice of interest representation. Ringe, ${ }^{3)}$ however, presents a focal-point model as an attempt to explain the policy preference formation in legislative politics,

1) P. Hausemer, "Participation and Political Competition in Committee Report Allocation. Under What Conditions Do MEPs Represent Their Constituents?" European Union Politics 7-4 (2006), pp. 505-30; C. Wlezien, "Patterns of Representation: Dynamics of Public Preferences and Policy," Journal of Politics 66- 1 (2004), pp. 1-24.

2) To name a few, G. Cox and M. McCubbins, "On the Decline of Party Voting in Congress," Legislative Studies Quarterly XVI-4 (1991), pp. 547-70; M. Morelli, "Demand Competition and Policy Compromise in Legislative Bargaining," American Political Science Review 93-4 (1999), pp. 809-20; A. Kreppel, "Rules, Ideology and Coalition Formation in the European Parliament: Past, Present and Future," European Union Politics 1-3 (2000), pp. 340-62. For comprehensive citation, see C. Carrubba et al., "Selection Bias in the Use of Roll Call Votes to Study Legislative Behavior," European Parliament Research Group Working Paper, No. 11 (2003).

3) N. Ringe, "Policy Preference Formation in Legislative Politics: Structures, Actors, and Focal Point," American Journal of Political Science 49-4 (2005), pp. 731-45. 
examined in the context of the European Parliament(EP). He argues that ideology and constituency interests together shape legislators' policy preferences but the influence of the two depends on how the issue of the given legislation is framed through certain focal points. Although the model provides a more sophisticated explanation of the formation of legislators' policy preferences than previously available, its assumption that MEPs' (members of the European Parliament) constituency interests are unitarily formed by national interests is rather a simplistic view of the constituency interests in the setting of multi-level governance. The identification of both and constituency interests is usually more complex because of the competition between different sectoral interests within a member state or a constituency.

To address this gap in the literature, I attempt to investigate legislators' policyseeking behavior through the lens of issue saliency with a case study of MEPs' voting on Directive 2001/37/EC of the European Parliament and of the Council of 5 June 2001 on the approximation of the laws, regulations and administrative provisions of the Member States concerning the manufacture, presentation and sale of tobacco products (the 'Tobacco Products Directive', henceforth). I propose that, from the legislators' point of view, there are two channels in the formation of policy preferences: ideology and constituency. To be represented by a legislator, an interest needs to be both compatible with and salient to his/her ideology or constituency. I test this proposition in the context of the European Union. Investigating the formation of policy position in the conflict of different special interests including constituencies is particularly crucial in a supra-national setting such as the EU because the weak link between the members of the European Parliament (MEPs, henceforth) and their electorates leaves MEPs' policy choices little scrutinized by their voters. MEPs are representatives of the European Union's citizens and are elected through nationally organized elections as members of national parties. Policy making is more complex to the public at the EU level than the national level, however, and the mandate from citizens to MEPs is opaque. Under such circumstances, reflecting their representational role is a challenge for MEPs. National parties, the European Parliamentary groups, and national governments often point out different groups to represent.

This article proceeds with a brief explanation of policy making in the European Parliament with respect to tobacco regulation. Hypotheses about MEPs' policy-seeking behaviour are generated with discussion of two channels of interest representation. The hypotheses are tested with statistical analyses of eight roll call votes in the EP, with conclusions drawn from the results. 


\section{II . Policy-seeking by Amendment}

The European Parliament pursues its policy preferences mainly by means of legislative amendment. With the Commission as the sole initiator of legislation, the EP has the right to amend legislative initiatives in two subsequent legislative readings under the so-called 'codecision procedure' according to which the Tobacco Products Directive was adopted. The EP amends the Commission's legislative proposals by specifying the content of bills in ways that promote certain policy outcomes. The final adoption of the legislation under the codecision procedure requires the agreement of the EP and the Council of the European Union, which represents national governments.

The Tobacco Products Directive recasts three older directives that regulated tar content in cigarettes, oral tobacco and labeling of tobacco products. ${ }^{4)}$ It substantially increases the level of regulation in favor of health and expands the scope of EU regulation of tobacco products by replacing national provisions with EU standards in those areas. Its major focus concerns the approximation of member states' national laws governing (i) ingredients in tobacco including the maximum tar, nicotine and carbon monoxide yields of cigarettes; and (ii) information to appear on unit packets of tobacco products showing health warnings, the ingredients and descriptions of tobacco products.

This directive is good for studying MEPs' behavior as they select between the various policy interests they represent. Diverse interests are involved in tobacco control. The conflict between public interests and private interests including the individual right to make consumption choices are complex in the case of tobacco control. Tobacco control involves the tobacco industry, tobacco farmers, organized interest groups in the form of public health groups as well as unorganized interests such as smokers and non-smokers at both the EU level and national levels.

Regulating the market in tobacco has traditionally been viewed and depicted from two angles. On the one hand, it concerns finding a balance between "intruding in the private lives, free consumer choices and established rights of self-governing individuals, versus the responsibility of citizens to manage risks and to avoid harming others, in favour of the former." ${ }^{5)}$ On the other hand, it is a struggle between those advocating the public

4) Council Directive 1989/622/EEC of 13 November 1989 on the approximation of the laws, regulations and administrative provisions of the Member States concerning the labeling of tobacco products; Council Directive 1990/239/EEC of 17 May 1990 on the approximation of the laws, regulations and administrative provisions of the Member States concerning the maximum tar yield of cigarettes; and Council Directive 1992/41/EEC of 15 May 1992 amending Directive 1989/622/EEC on the approximation of the laws, regulations and administrative provisions of the Member States concerning the labeling of tobacco products. 
health (and seeking to reduce the possible cost to national health schemes of smokingrelated diseases) and those protecting the tobacco industry (and securing jobs and government revenues derived from the tax on tobacco). Clashes between public and sectoral interests are profound in this respect, given the sizeable tax revenues derived from tobacco sales, which amount to EUR 70 billion in the EU member states. ${ }^{6}$ Additionally, like other policy making at the EU level, the debate on the competences of the EU in the tobacco regulation causes another division. Whereas some argue that certain aspects of regulating the tobacco market should be under the power of national governments, others promote the role of the EU in the ever more transnationalized tobacco market. For instance, Nicole Thomas-Mauro MEP, on behalf of the UEN Group, voiced reservations about the directive, saying that it went beyond the EU's competences. ${ }^{7)}$

The legislative process of the Tobacco Product Directive started with the Commission's presentation of the initial proposal for the directive on 16 November 1999 and practically ended when, on 27 February 2001, the final text of the directive was adopted by the Conciliation Committee and later endorsed by the Council and the EP respectively. The final text was by and large the middle ground between the positions of the two. The position of various actors on the Tobacco Products Directive in general and the final legislative outcome can be summarized as a one-dimensional spatial model shown in Figure 1. The tobacco industry used the threat of job losses as the grounds for their opposition to strict tobacco control, as they had also done in the late 1980s when the original directive was adopted. In the end, however, the resultant directive in 2001 by and large bypassed the influence of the tobacco industry. ${ }^{8)}$

Figure 1. Actors' Positions on Tobacco Control

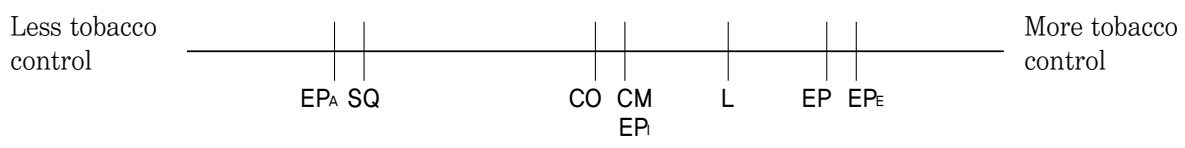

$$
\begin{aligned}
& \text { EPA : EP Agriculture Committee median } \\
& \text { EPI : EP Industry Committee median } \\
& \text { EPE : EP Health Committee median } \\
& \text { EP : EP plenary median }
\end{aligned}
$$$$
\mathrm{SQ}: \text { Status quo }
$$$$
\mathrm{CO}: \text { Commission }
$$$$
\mathrm{CM} \text { : Council of Ministers }
$$$$
\mathrm{L} \quad \text { : Final legislative outcome }
$$

5) A. Cooper and P. Kruzer, "Germany's Non-War against Smoking and the Tobacco Policy of the European Union" (2002), unpublished manuscript.

6) F. Duina and P. Kurzer, "Smoke in Your Eyes: The Struggle over Tobacco control in the European Union," Journal of European Public Policy 11-1 (2004), pp. 57-77; Langen, Debates of the European Parliament, Sittings of 13 June 2000.

7) Debates of the European Parliament, Sittings of 11 December 2000.

8) Debates of the European Parliament, Sittings of 14 May 2001. 
I choose to analyze the amendments taken by roll call at the first reading of the EP because in the first reading the EP places amendments on the Commission's proposal before the Council of Ministers' acts. Unconstrained by the Council's position, MEPs are expected to be more expressive in the first reading. The default outcome of a vote on an $\mathrm{EP}$ amendment in the first reading is the corresponding text in the proposal of the Commission. If a simple majority of the votes cast in the EP plenary fails to adopt an amendment, the EP will adopt the corresponding part proposed by the Commission without any change. In other words, voting against an amendment is equivalent to voting for the text proposed by the Commission. Thus, the item under consideration when MEPs voting on an amendment in the first reading is the difference between the text proposed by the Commission and the amendment placed on it by the EP. Throughout the process of adopting the directive, the EP took 11 roll call votes in total, nine in the first reading. I analyze eight of these, excluding one that had only procedural implications. Table 1 shows the summary of these amendments adopted by the roll call vote in the first reading.

Table 1. Amendments Taken by Roll Call Votes for the Tobacco Product Directive

\begin{tabular}{|c|c|}
\hline Name of EP Amendment & Changes made by the Amendment to the Commission Proposal \\
\hline CAP & $\begin{array}{l}\text { Criticism against the Common Agricultural Policy (CAP) fund for } \\
\text { tobacco growing. }\end{array}$ \\
\hline Constraint 1 , earlier report & $\begin{array}{l}\text { Forwarding the date of Commission's report by a year to } 31 \\
\text { December } 2004 .\end{array}$ \\
\hline $\begin{array}{l}\text { Constraint } 2 \text {, consulting } \\
\text { tobacco industry }\end{array}$ & $\begin{array}{l}\text { Including the tobacco industry in the working group that would deal } \\
\text { with further tobacco regulation. }\end{array}$ \\
\hline Warning size, ingredient & $\begin{array}{l}\text { Increasing size of warning on package of tar, nicotine and carbon } \\
\text { monoxide yields to } 30 \%, 35 \% \text { and } 40 \% \text { depending on the number of } \\
\text { official language, other than the Commission's initial proposal of } \\
10 \%, 12 \% \text { and } 15 \% \text {. }\end{array}$ \\
\hline Warning size, general & $\begin{array}{l}\text { Increasing the size of the general warning to } 35 \%, 37 \% \text { and } 40 \% \\
\text { depending on the number of official language, other than the } \\
\text { Commission's initial proposal of } 25 \%, 27 \% \text { and } 30 \% \text {. }\end{array}$ \\
\hline Warning size, additional & $\begin{array}{l}\text { Increasing the size of the additional warning to } 45 \%, 47 \% \text { and } 50 \% \\
\text { depending on the number of official language, other than the } \\
\text { Commission's initial proposal of } 25 \%, 27 \% \text { and } 30 \% \text {. }\end{array}$ \\
\hline Detailed warning & Adding more detailed warning. \\
\hline Warning, "addictive" & Adding "addictive" to the warning. \\
\hline
\end{tabular}


How did MEPs make their voting decision on these amendments? The premise for my hypotheses is that an MEP is more likely to vote for an EP amendment when the amendment is expected to advance his preferred policy outcomes. More specifically, I hypothesize that MEPs form their policy preferences based on the policy preferences of groups whose interests are salient on the given issue dimensions. As shown in Table 1, amendments can move the policy outcome of the Commission's initial position on a leftright dimension, an EU integration dimension, or a (more-or-less) regulation dimension. These policy implications of amendments induce MEPs to vote in the way that maximizes their policy interests. Considering the Commission's initial proposal and the EP amendment, they choose the one more favorable for their policy preferences.

Then how do MEPs form their policy preferences? The positions of all the groups they represent are classified into three sources of policy interests: the member states as MEPs constituencies, their national parties, and societal actors, including the tobacco industry, health groups, and smokers. The first two groups function as channels through which the interests of the last group are to be selected in the policy preferences of MEPs. In other words, the degree of inclusion of the third group's interests depends on the extent to which they are identified as those of either member states or national parties. More importantly, this paper finds that member states as constituencies are more influential over MEPs than the literature of the EP voting has suggested so far. The literature has focused on the national parties as the driving force of MEPs' reelection seeking behavior. ${ }^{9)}$ Although this is a more subtly formed argument than that argued by (liberal) intergovernmentalism, ${ }^{10)}$ which treats the member states' interests as identical to the positions of the member state governments. Whereas institutional constraints are exogenously given, the combination of these groups' interests endogenously forms MEPs' policy interests. I recognize that these groups also can be a source of the pressure, such as party discipline, causing MEPs to pursue policies other than their ideal policy. However, I assume that MEPs' choice to pursue these groups' policy preferences form balanced sets of policy preferences they represent rather than circumventing these policy ideas due to institutional constraints. Hypotheses about MEPs' behavior when pursuing those interests is examined in the next section.

9) For citation, see S. Hix et al., "Dimensions of Politics in the European Parliament," American Journal of Political Science 50- 2 (2006), pp. 494-511.

10) A. Moravcsik, The Choice for Europe (Ithaca: Cornell University Press, 1998). 


\section{Hypotheses}

Like other legislators, MEPs pursue their policy preferences (formed by the policy interests of various groups including business interests, NGOs, and other societal actors) at both the EU and the national levels. ${ }^{11}$ These groups influence the policy preferences of MEPs through roughly two channels of representation: an ideologically driven channel such as national parties and EP party groups, and a constituency-driven channel such as member states.

Above all, the national parties matter most for MEPs in shaping their positions on issues in terms of left-right ideology and EU integration. Each MEP represents his or her ideologically driven interests based on national party and EP party groups. As their chance of being re-elected is in the hands of the national parties ${ }^{12)}$ and the parties are effective actors in policy making, MEPs join the parties to which their own policy preferences are closest. The national parties belong to the EP party groups with which their ideological orientation is most compatible. The vast literature in the study of the European Parliament argues that the politics in the European Parliament is ideologically based, with MEPs voting along the left-right ideological dimension rather than on nationality. ${ }^{13)}$ The EP parliamentary groups are the backbones on which supranational policy positions are formed by the national party delegations belonging to them. The receptiveness of national parties and EP party groups to different societal actors depends on how compatible the ideological position of the former is with the interests of the latter.

In the case of Tobacco Products Directive, the prominent supporters of stricter tobacco control comprise public health NGOs like the European Network for Smoking Prevention and the European Cancer Leagues. A recent special Eurobarometer poll on attitudes toward smoking and public health also suggests that non-smokers might be expected to support more tobacco control. ${ }^{14)}$ The opponents of tougher tobacco regulation were led by the tobacco industry including tobacco growing farmers. Although groups representing smokers did not play a major role, ${ }^{15)}$ one can expect smokers to oppose higher levels of

11) C. Neuhold, "Bridging the Gap? Members of the European Parliament between Action Constraints and (New) Demands," unpublished manuscript (2002); P. Bouwen, "The Logic of Access to the European Parliament: Business Lobbying in the Committee on Economic and Monetary Affairs," Journal of Common Market Studies 42-3 (2004), pp. 473-495.

12) S. Hix, "Parliamentary Behavior with Two Principals: Preferences, Parties and Voting in the European Parliament," American Journal of Political Science 46-3 (2002), pp. 688-698.

13) S. Hix, et al., "Power to the Parties: Cohesion and Competition in the European Parliament, 1979-2001?" British Journal of Political Science 34-4 (2005), pp. 767-793.

14) European Commission (2006) Attitudes of Europeans toward Tobacco. Special Eurobarometer. 239. Online at http://ec.europa.eu/public_opinion/archives/ebs/ebs_239_en.pdf. 
tobacco control.

Among these groups, the left are more likely to represent the proponents of stricter tobacco regulation as they are ideologically more supportive of regulatory measures for public interests. The left are also generally less industry-friendly than the right, being less sympathetic toward the tobacco industry. Similarly the pro-EU parties are likely to support the EU-wide measure of tobacco control and vice versa. Thus Hypothesis 1 is as below:

Hypothesis 1-1: An MEP from a more left-leaning national party is more likely to support stricter tobacco control.

Hypothesis 1-2: An MEP from a more pro-EU national party is more likely to support EU-wide tobacco regulation.

On the other hand, MEPs have constituency interests to represent. Broadly speaking, although the linkage between individual constituents and MEPs is weak, the member states are MEPs' constituencies as European elections are nationally based. It may not be hugely helpful for their national parties' electoral success, but MEPs are still under pressure to legitimize their legislative activities as being responsive to voters' interests because of their perceived role in national parties. This is different from the intergovernmental model proposed by Moravcsik in which national interests are mainly determined by economic interests. Following his logic, national interests should be exogenously given to MEPs. From time to time, national governments contact their MEPs to enhance their positions in the EP. ${ }^{16)}$ More often, however, MEPs need to pick and choose some of multiple competing interests within their constituencies. My proposition is that they choose the interests with high saliency for the concerned group. The more saliency the group attaches to their interest, the greater incentive the MEPs to promote them, because they can claim more credit for representing them. Those interests may be salient as to be presented in the form of a highly organized lobbying campaign by the tobacco industry. Other societal actors, such as consumers of the tobacco products, are not organized but are attentive to policy outcomes. Although they may not voice their opinion explicitly in the policy-making process, they have the potential to react to the outcome once the policy is implemented. In this case, the

15) S. Princen, "Advocacy Coalitions and the Internationalization of Public Health Policies," Journal of Public Policy 27-1 (2007), pp. 13-33.

16) T. Raunio, "Beneficial Cooperation or Mutual Ignorance? Contacts between MEPs and National Parties," in B. Steunenberg and J. Thomassen (eds.), The European Parliament. Moving toward Democracies in the EU (Oxford: Rowman and Littlefield Publishers, 2002). 
legislators cannot easily deviate from their interests without putting their political popularity, if not electoral success, at risk. ${ }^{17)}$ It should be noted that I assume these interests are nationally based, giving a varying degree of saliency to represent them to MEPs belonging to different member states.

Constituency-based interests with respect to tobacco control are two-fold: diffuse interests advocating for public health and concentrated interests opposing stricter tobacco control. To begin with, as representatives of their national constituencies, MEPs may be concerned about the impact of legislation on national public health. The benefit of tougher tobacco product regulation will be bigger for countries with higher smoking rates since more of the population is exposed to the dangers of smoking. For instance, this may lead one to expect MEPs to vote in favor of the amendments making the warnings on the tobacco packages stricter, if their member states have higher rates of smokers in the population. Since it is argued that smoking causes many kinds of diseases and consequently a higher smoking rate increases the financial burden for the national health schemes, MEPs from these member states may be more concerned about reducing tobacco consumption and prefer stricter regulation.

However, MEPs do not form their policy preferences exclusively from the public health concerns since the gains of promoting public health through tobacco regulation are almost unrecognizable for the public. Taking saliency into account, MEPs also need to woo other groups among their electorates, who have vested interests in pursuing issues other than the diffused public health. Tobacco regulation is more salient for these groups than for the rest of the population. Therefore, the bigger these vested interests, the more likely MEPs are to incorporate their interests as a part of their policy preferences.

The first group for whom the tobacco regulation is salient is smokers. This leads me to hypothesize that the smoking rate of a constituency can have the opposite impact on the formation of MEPs' position on controlling tobacco products to that predicted from the public health concerns argument. The tobacco products regulation is much more salient for smokers than non-smokers. The Tobacco Products Directive is an anti-smoking policy that has direct effects only on smokers, i.e., the consumers of tobacco products. Non-smokers are not likely to encounter the policy outcome. The above mentioned Eurobarometer poll on attitudes towards smoking reveals that generally non-smokers are more supportive of tighter tobacco regulation than smokers. Whereas non-smokers might not even have been aware of the regulation, stricter tobacco products regulation may invoke resistance and displeasure from smokers, who do not wish state intervention

17) A. Dur and D. de Bievre, "The Question of Interest Group Influence," Journal of Public Policy 271 (2007), pp. 1-12. 
in their private lives. As credit-seekers from their policy positions, MEPs are more likely to oppose to toughening the tobacco products regulation if their constituency has a bigger proportion of smokers.

Moreover, with the same Eurobarometer data I ran correlation analyses between the national attitude to tobacco control and the proportion of smokers in the EU member states and found that there is negative relationship between the public support for tobacco regulation and the smoking rate. The Pearson's correlation coefficient is -.509 at the 0.05 significance level with 15 observations (i.e., 15 EU member states). Higher smoking rate countries tend to be more tolerant toward smoking. Apart from the uneven saliency of tobacco control for smokers and non-smokers, sharing a national culture on smoking seems to induce MEPs from member states with larger smoking populations to resist stricter tobacco control in general.

As for the second group, MEPs also form their policy preferences from the vested economic groups with interests in tobacco control: the tobacco industry and tobacco growing farmers in their constituencies. Those from member states with a larger tobacco industry and more tobacco subsidies are assumed to be more exposed to lobbies from these groups. The industry actively lobbied the national government and MEPs, arguing that increases in the level of regulation would lead to job losses. They threatened to move their business outside the EU if severe controls were imposed on the tobacco market. ${ }^{18)}$ Lobbying from the tobacco industry may induce MEPs to object to higher standards for both the contents and packaging of tobacco products. As for tobacco growing farmers, with regard to the amendment that concerns the EU's Common Agricultural Policy (CAP), I hypothesize that MEPs from the member states gaining the bigger sum of subsidies for tobacco production will be more likely to vote against the amendment, which criticizes the CAP.

In sum, my second hypothesis is:

Hypothesis 2: An MEP is more likely to support stricter tobacco control if he or she is from a member state with lower smoking-rate/smaller tobacco industry/smaller EU tobacco subsidy.

As the policy interests reaching MEPs through these two channels (i.e., ideologicallybased national parties and member-state-based constituencies) may provide conflicting policy preferences, balancing them is the way in which MEPs form their policy

18) Debates of the European Parliament, Sittings of 14 May 2001. 
preferences. It should be noted that I do not argue that MEPs exclusively promote the interests of those to whom the regulation is salient. I simply argue that MEPs are more likely to form their policy positions at the expense of public interests if those groups opposing a given policy are larger in their constituencies. Also, I do not examine which channels of interests between national parties and constituencies MEPs prioritize. The representational role of MEPs is hardly studied with exception of Katz and Wessels (1999) and Scully and Farrell (2003). ${ }^{19)}$ Even for them, the focus of research is how MEPs perceive their role as representative of various interests rather than how they play the role in practice -- i.e. policy making by legislative voting -- especially when they cannot pursue all the interests at the same time. I recognize that the influence of these channels may vary among MEPs because of differences in the electoral systems and their backgrounds although for simplicity I do not include them in the analysis.

These hypotheses, however, should be tested with some caveats. Institutional constraints may prevent MEPs from voting sincerely as the hypotheses predict. I do not deny that, like other legislators, MEPs pursue their policy preferences under the constraints imposed by their legislative environment, such as its internal voting rules and the treaty-required cooperation with other EU institutions. However, my purpose is to examine the policy-seeking behavior of MEPs despite such institutional constraints. As the first reading votes under the codecision procedure are the sample that is least biased, letting MEPs vote more sincerely than in the second reading, I test the hypotheses with the votes on the first reading amendments of the Tobacco Products Directive in the next section.

\section{Statistical Analysis}

\section{Variables}

To test the hypotheses, with logit regression I examine the roll call votes taken on the first-reading amendments adopted for the Tobacco Products Directive. I present the results of the analysis in Tables 3 and 4. In order to present them in a more straightforward way, I group the results according to the contents of the amendments,

19) R. Katz and B. Wessels (eds.), The European Parliament, National Parliaments and European Integration (Oxford: Oxford University Press, 1999); R. Scully and D. Farrell, "MEPs as Representatives: Individual and Institutional Roles," Journal of Common Market Studies 412 (2003), pp. 269-288. 
such as criticism of the EU tobacco subsidy, administrative procedures to be taken by the Commission, and sizes and contents of warning labels. As those amendments sharing the same issues have similar implications, the expected influence of independent variables on the behavior of MEPs are the same.

The dependent variable is a dummy variable showing how an MEP voted. Its value is 1 if the MEP voted for the EP amendment. It is 0 if he or she voted against the amendment or abstained. The abstention is treated as equivalent to a nay vote because, when an absolute majority of votes cast is required, as in the case of the EP first reading, abstaining has the same effect as voting against the given item. Thus, treating nay votes identical to abstention still does not cause an analytical problem.

As for independent variables, the variables of left-right ideology and the EU integration denote MEPs' preferences on these issues. I use the national party scores by Budge et al. for the left-right ideology and those by Marks and Steenbergen for EU integration. ${ }^{20)}$ In order to indicate the national interest in public health with respect to tobacco control, I use the national rates of smokers in the population drawn from the World Health Organization (WHO) report on tobacco control. From the same report, I adopt the numbers of employees in tobacco industry in the member states, which I take as an indication of the pressure on MEPs to represent the tobacco industry's interests. Indicating the influence of tobacco growing farmers, the shares of individual member states in the European Agricultural Guidance and Guarantee Fund (EAGGF) under the Common Agriculture Policy (CAP) for tobacco growing are taken from the Commission report. All the records of member states concerning tobacco control are shown in Table 2.

20) I. Budge, H.D. Klingemann, A. Volkens, J. Bara, and E. Tanenbaum, Mapping Policy Preferences. Estimates for Parties, Elections, and Governments 1945-1998 (Oxford: Oxford University Press, 2001); G. Marks and M. Steenbergen, "Understanding Political Contestation in the European Union,” Comparative Political Studies 35-8 (2002), pp. 879-892. 
Table 2. National Statistics in Tobacco Regulation

\begin{tabular}{lccccc}
\hline $\begin{array}{l}\text { Member } \\
\text { state }\end{array}$ & $\begin{array}{l}\text { Adult } \\
\text { smoking } \\
\text { rate (per- } \\
\text { cent) }^{1}\end{array}$ & $\begin{array}{l}\text { Number of } \\
\text { workers in } \\
\text { tobacce } \\
\text { manufacturing }\end{array}$ & $\begin{array}{l}\text { Tobacce excise tax } \\
\text { revenue as a } \\
\text { proportion of total tax } \\
\text { revenue (percent) }\end{array}$ & $\begin{array}{l}\text { (pAGGF 1999 } \\
\text { (Euro million) })^{3}\end{array}$ & $\begin{array}{l}\text { Support for } \\
\text { smoking ban in } \\
\text { bars or pubs } \\
\text { (percent) }^{4}\end{array}$ \\
\hline Austria & 24.5 & 1,756 & 2 & 7 & 43 \\
Belgium & 28.0 & 4,400 & 2 & 3.6 & 56 \\
Denmark & 30.5 & 1,415 & 3 & 0 & 48 \\
Finland & 23.5 & 700 & 2 & 0 & 74 \\
France & 34.5 & 4,400 & 2 & 67.6 & 6 \\
Germany & 35.0 & 15,455 & 2 & 23.2 & 45 \\
Greece & 38.0 & 9,943 & 9 & 374.2 & 56 \\
Ireland & 31.5 & 1,279 & 5 & 0 & 81 \\
Italy & 24.9 & 13,330 & 2 & 349.2 & 88 \\
Luxembourg & 33.0 & - & - & 0 & 53 \\
Netherlands & 33.0 & 4,739 & 2 & 0 & 46 \\
Portugal & 18.7 & 1,193 & 4 & 18.3 & 69 \\
Spain & 33.4 & 9,277 & 3 & 70.6 & 62 \\
Sweden & 19.0 & 560 & 1 & 0 & 82 \\
UK & 26.5 & 6,450 & 4 & 0 & 67 \\
\hline
\end{tabular}

1. The Tobacco Atlas, http://www.who.int/tobacco/statistics/tobacco_atlas/en/.

2. Ayda Yurekli, "Design and Administer Tobacco Taxes," in Ayda Yurekli \& Joy de Beyer (eds.) World Bank Economics of Tobacco Toolkit, http://www1.worldbank.org/tobacco/pdf/Taxes.pdfEuropean.

3. Commission, 29th Financial Report on the European Agricultural Guidance and Guarantee Fund (E.A.G.G.F.) - Guarantee Section, http://europa.eu.int/comm/agriculture/fin/finrep99/index_en.htm.

4. Attitudes of Europeans toward tobacco, Special Eurobarometer, p. 239.

To control for the institutional implications of the EP amendments, I use a variable to measure the policy differences between MEPs and the Commission. More specifically, I attempt to examine the implications of the first reading amendments for the relationships between MEPs and the Commission. I speculate that the more distant the Commission's ideal policy position is from the ideal policy position of an MEP, the more likely he or she is to vote for amendments since he or she expects the Commission to share his or her policy preferences. This is more likely to be the case when the legislators like MEPs need to rely on the bureaucracy (i.e., the Commission) to obtain information on the given legislation due to its complexity and technicality. Where they have less understanding of a policy area, legislators are forced to trust the judgement of the bureaucracy, which has more resources for collecting information and expertise. Knowing that the bureaucracy may pursue its own policy agenda, the legislators are more likely to support the bureaucracy when it has similar policy preferences to theirs. 
Including the variables enables one to test how the policy difference between MEPs and the Commission affect MEPs' behavior on amending the Commission's proposal per se. As I use the individual MEP scores on the two first dimensions produced by applying the Nominate scaling method to the roll-call votes in the EP Nominate data by Hix, Noury, and Roland, ${ }^{21}$ this will also address the issue of giving same values to MEPs belonging to the same national parties. For the Commission, I assume that each Commissioner has the same position as the mean position of MEPs from his or her national party. I then calculate the position of the Commission as a whole as the two-dimensional median by taking the mid-point of the $10^{\text {th }}$ and $11^{\text {th }}$ Commissioner in both dimensions. I calculate the distance between each MEP and the Commission as the two-dimensional Euclidean distance between his or her two-dimensional location and the two-dimensional location of the Commission.

Finally, I add a dummy variable controlling for the ties between the Commission and an MEP. It shows whether the national party of an MEP has a Commissioner in the present Commission. It is 1 if the national party has a Commissioner, and 0 otherwise. National partisanship can function as a route of communication between MEPs and the Commissioners. Belonging to the national parties with no Commissioner, MEPs are deprived from this benefit of informal communication with the Commission. With the same logic, MEPs having this route to the Commission would be less in favor of changing the Commission's initial proposal that has already incorporated their policy preferences.

\section{Results}

A quick glance at Tables 3 and 4 shows that my hypotheses are generally confirmed. As predicted by Hypothesis 1, national parties' positions on the left-right ideology and EU integration influence MEPs' voting on the Tobacco Products Directive. MEPs from the left-wing parties are likely to support stricter tobacco control than those from the right. MEPs pursue EU integration more if their parties are more supportive of EU integration. Hypothesis 2 is also confirmed. MEPs are more likely to respond, at the expense of public interests, to those actors for whom the Tobacco Products Directive is salient, if those actors comprise bigger groups in their constituency. The smoking rate, the size of tobacco industry, and the amount of the EU subsidy for tobacco growing have a negative impact on MEPs' support for tougher tobacco control. I explain MEPs' voting behavior on the amendments below in more detail.

21) S. Hix et al., "Power to the Parties," pp. 767-793. 
Table 3. Coefficients of Logit Regression on the Roll Call Votes of MEPs on the Tobacco Subsidy Amendments

\begin{tabular}{|c|c|c|c|c|c|c|}
\hline Independent Variable & $\mathrm{HI}$ & CAP & $\mathrm{HI}$ & $\begin{array}{l}\text { Earlier } \\
\text { report }\end{array}$ & $\mathrm{HI}$ & $\begin{array}{c}\text { Consulting } \\
\text { tobacce } \\
\text { industry }\end{array}$ \\
\hline Left-Right ideology & - & $\begin{array}{c}-.03^{* *} \\
(.00)\end{array}$ & - & $\begin{array}{c}-.02^{*} \\
(.01)\end{array}$ & - & $\begin{array}{l}.06^{* *} \\
(.01)\end{array}$ \\
\hline EU integration & - & $\begin{array}{c}-.41^{* *} \\
(.09)\end{array}$ & + & $\begin{array}{l}.66^{* *} \\
(.20)\end{array}$ & & $\begin{array}{l}.60^{* *} \\
(.14)\end{array}$ \\
\hline National rate of smokers & - & $\begin{array}{c}-9.15^{* *} \\
(2.69)\end{array}$ & - & $\begin{array}{c}-18.12^{*} \\
(7.29)\end{array}$ & & $\begin{array}{c}.28 \\
(3.64)\end{array}$ \\
\hline No. of employees in tobacco industry & - & $\begin{array}{l}.024 \\
(.02)\end{array}$ & - & $\begin{array}{l}.05 \\
(.06)\end{array}$ & + & $\begin{array}{l}-.06 \\
(.04)\end{array}$ \\
\hline CAP subsidy for tobacco growing & - & $\begin{array}{c}-.01^{* *} \\
(.00)\end{array}$ & & & & \\
\hline Policy difference from the Commission & & $\begin{array}{c}.64 \\
(.50)\end{array}$ & & $\begin{array}{l}-2.70 \\
(1.52)\end{array}$ & & $\begin{array}{c}-1.84 \\
(.93)\end{array}$ \\
\hline NP with Commissioners & & $\begin{array}{c}-.65^{*} \\
(.23) \\
\end{array}$ & & $\begin{array}{l}1.06 \\
(.73) \\
\end{array}$ & & $\begin{array}{c}1.95^{* *} \\
(.35) \\
\end{array}$ \\
\hline $\begin{array}{l}\text { No. of observations } \\
\text { LR ch2 } \\
\text { Prob>chi2 } \\
\text { Pseudo } \text { R }^{2}\end{array}$ & & $\begin{array}{c}468 \\
135.01 \\
.00 \\
.20\end{array}$ & & $\begin{array}{c}461 \\
76.05 \\
.00 \\
.36\end{array}$ & & $\begin{array}{l}466 \\
173.75 \\
.00 \\
.39\end{array}$ \\
\hline
\end{tabular}

Note: HI is Hypothesised Influence. Standard errors are in parentheses.

**=significant at 0.001 level; * =significant at 0.01 level.

Constants are included in the model but not reported.

To begin with, Table 3 shows the result of the logit regression of the vote on the amendment that criticizes the Common Agricultural Policy for subsidizing tobacco growers. Over EUR 1 billion is spent annually on subsidies. ${ }^{22)}$ Although the directive does not directly regulate subsidies for tobacco growing, discussing the issue only in the preamble rather than the main body of the directive, the amendment may be still effective as the European Court of Justice uses the preamble for interpreting legislation. ${ }^{23)}$ Some MEPs indeed felt it necessary to insert the EP's objection to subsidization of the tobacco growing in the directive because "it was unreasonable for the Union to put the large sums of money into tobacco-growing," and at the same time to suppress tobacco consumption for

22) Blokland, Debates of the European Parliament, Sittings of 14 May 2001.

23) G. Tsebelis and A. Kalandrakis, "The European Parliament and Environmental Legislation," in B. Steunenberg and J. Thomassen (eds.), The European Parliament. Moving toward Democracies in the Eu (Oxford: Rowman and Littlefield, 2002). 
public health. ${ }^{24)}$

Confirming Hypothesis 1, the leftist and less pro-EU MEPs are more likely to support criticisms of EU funds for growing tobacco. As for Hypothesis 2, national and sectoral interests form MEPs' policy preferences along with party positions on EU integration and left-right ideology. MEPs from the member states gaining bigger shares from the EU tobacco subsidy objected to the amendment. A greater number of smokers in a member state induced MEPs to vote against criticism of the subsidy. This implies that MEPs are more influenced by their national smoking culture and smokers than by concern for national health schemes. I return to this point later when I discuss other amendments.

Table 3 also presents the logit regression of MEPs' votes on the amendments to Article 10 of the Tobacco Products Directive regarding the procedural constraints on the Commission. An amendment to the article sets the date by which the Commission should submit a report on the application of the directive and make further proposals to amend it in order to adjust it to the certain changes of tobacco market as 31 December 2004 rather than 31 December 2005 as proposed by the Commission. Since the forthcoming report and proposals were expected to extend and strengthen the tobacco control at the European level, requiring their earlier submission also has the effect of increasing the level of regulation and promoting EU integration. Reducing the time available for the Commission by a year, it would increase the constraints on the Commission or, in other words, reduce the amount of discretion of the Commission. The last amendment in the table promotes the rightist ideology and interests of the tobacco industry by obliging the Commission to consult the tobacco industry. It also increases the level of procedural constraints imposed on the Commission by adding more actors whom the Commission must consult.

MEPs' preferences on left-right ideology and EU integration have the expected effects on MEPs' voting on the amendment bringing forward the date of the Commission's report (Earlier Report) and on the amendment adding tobacco industry representatives to the advisory group (Consulting Tobacco Industry). The leftist MEPs were prone to pursue stricter regulation in the former, whereas the rightist MEPs were in favor of giving opportunities to the tobacco industry to participate in the Commission's policy making in the latter. The pro-EU MEPs were supportive of speeding up the integration process in the tobacco market as shown in the "Earlier Report" amendment. This amendment did not gain much support from MEPs whose member states had higher smoking rate, either.

24) Sjostedt, Debates of the European Parliament, Sittings of 11 December 2000. 
Table 4. Coefficients of Logit Regression on the Roll Call Votes of MEPs on Increasing the Sizes of Warnings

\begin{tabular}{lcccccc}
\hline Independent Variable & $\begin{array}{c}\text { Warning } \\
\text { size, } \\
\text { ingredient }\end{array}$ & $\begin{array}{c}\text { Warning } \\
\text { size, } \\
\text { general }\end{array}$ & $\begin{array}{c}\text { Warning } \\
\text { size, } \\
\text { additional }\end{array}$ & HI & $\begin{array}{c}\text { Detailed } \\
\text { Warning }\end{array}$ & $\begin{array}{c}\text { Warning } \\
\text { "addictive" }\end{array}$ \\
\hline Left-Right ideology & $-.04^{* *}$ & $-.03^{* *}$ & $-.04^{* *}$ & $.03^{* *}$ & $-.02^{* *}$ \\
EU integration & $(.00)$ & $(.00)$ & $(.00)$ & $(.00)$ & $(.00)$ \\
& $-.35^{* *}$ & $-.43^{* *}$ & $-.46^{* *}$ & $.95^{* *}$ & $-.55^{* *}$ \\
National rate of smokers & $(.10)$ & $(.10)$ & $(.10)$ & $(.14)$ & $(.09)$ \\
& $-8.66^{*}$ & $-7.41^{*}$ & $-9.89^{*}$ & - & .90 & $-8.83^{* *}$ \\
No. of employees in tobacco industry & - & .012 & $(2.91)$ & $(3.16)$ & $(3.20)$ & $(2.62)$ \\
& & $-.08^{* *}$ & $-.08^{* *}$ & $-09^{*}$ & .04 \\
Policy difference from the Commission & $6.02^{* *}$ & $-6.35^{* *}$ & $-5.96^{* *}$ & $-3.62^{* *}$ & $-4.04 * *$ \\
& $(.80)$ & $(.79)$ & $(.78)$ & $(.78)$ & $(.59)$ \\
NPs with Commissioners & $.86^{* *}$ & .42 & .46 & $.73^{*}$ & $1.00^{* *}$ \\
& $(.260)$ & $(.26)$ & $(.27)$ & $(.28)$ & $(.22)$ \\
\hline No. of observations & 463 & 461 & 456 & 458 & 471 \\
LR ch2 & 218.20 & 230.11 & 230.01 & 249.96 & 139.75 \\
Prob>chi2 & .00 & .00 & .00 & .00 & .00 \\
Pseudo R & .34 & 0.36 & .36 & .43 & .21 \\
\hline
\end{tabular}

Note: HI is Hypothesised Influence. Standard errors are in parentheses.

**=significant at 0.001 level; * =significant at 0.01 level.

Constants are included in the model but not reported.

Turning to the amendments concerning the sizes of the warnings on tobacco packages, Table 4 presents the results of logit regressions on the three votes on those amendments. All the amendments proposed larger sizes compared to those proposed by the Commission. As predicted, the left-right ideology of MEPs has a strong influence on their voting decisions as right-leaning MEPs tend to vote against increasing the size of warnings, regardless of the nature of the warnings. This confirms that they share the view of business interests more than their leftist counterparts do. The preference of the tobacco industry for smaller warnings had long been clear since it had heavily lobbied to reduce the size of warnings for the Council Directive 89/622/EEC. ${ }^{25}$ It also lobbied in 2001 for warnings covering only $10 \%$ of the cigarette packet. ${ }^{26)}$ Being supporters for big business in general, it is natural for the rightist MEPs to represent interests of tobacco industry advocating

25) A. Bitton, M. Neuman, and S. Glantz, Tobacco Industry Attempts to Subvert European Union Tobacco Advertising Legislation. Center for Tobacco Control Research and Education, University of Califonia, San Francisco (2002). Online at http://repositories.cdlib.org/ctcre/tcpmi/EU2002.

26) The Guardian, 16 May 2001. 
smaller warnings. The supports of the EU integration induce MEPs to object to the increase.

As for Hypothesis 2 on constituency-based interests, a national culture of smoking and the smokers' potentially resentful response to bigger warning on tobacco packages also shaped MEPs' policy preferences on the sizes of warnings. MEPs from member states having higher national rates of smokers tend to prefer a policy friendlier to tobacco consumption, i.e., smaller warnings. MEPs might have considered that it was more important to satisfy their smokers, as they are the electorates who would most directly feel the impact of the sizes of the warnings. Regulating the tobacco market was regarded as a way to intervene in the private lives of the people in general and the smokers in particular. If the general impact of the increased sizes of warnings would be an irritation to consumers rather than inducement to quit smoking, MEPs would have little incentive to incur the anger of smokers in their constituencies by supporting the increase of the warning sizes. Or, taking the cultural explanation into account, MEPs may merely exhibit an attitude toward smoking, which they learnt from their national culture. Those MEPs from the member states with higher rates of smoking may be more tolerant of smokers and more sympathetic to smokers' right to smoke.

As another constituency-based interest shaping MEP' policy preferences, the size of the tobacco industry measured by the size of employment in the sector also has a negative impact on MEPs' voting decisions on increasing the sizes of warnings. As I hypothesized, MEPs from member states with a bigger tobacco industry pursue more industry-friendly policies with respect to the sizes of warnings. The tobacco industry argued larger warnings would simply make tobacco packages less decorative. Industry objections to the EP amendments were also reflected in the report of the EP Industry Committee advocating smaller warnings than those proposed by the Commission. As the EP Environment, Public Health and Consumer Protection Committee advocated much tighter tobacco control than the EP median in line with public health groups, the EP Industry Committee formed an advocacy coalition with the Tobacco industry.

Moving on to the amendments that concern changing the contents of warnings, there are two amendments adopted by roll call vote as analyzed in Table 4. One amendment in the table calls for additional warnings on tobacco products other than smokeless or oral use tobacco. Another amendment added the word "addictive" for the warnings to smokeless or oral use tobacco. A quick glance at Table 4 shows that there are as many similarities as differences in the voting behavior of MEPs over these two votes.

The differences are caused by the fact that the contents of warnings have different implications. Although both amendments increased the level of regulation in tobacco products by virtue of using similar measures -- i.e., warnings --, the expected impact of 
these warnings vary depending on their nature. When making the words of warning more comprehensive (Detailed Warning), their readability has to be compromised since the sizes of warnings are fixed. Therefore, although the regulation on the warnings was strengthened by the amendment giving more lengthy and specific description of danger of smoking, its impact on reducing tobacco consumption was uncertain or even expected to be negative. ${ }^{27)}$ By contrast, inserting the word "addictive" (Warning, "addictive") would hardly change the general appearance of the packages, making its negative impact on tobacco consumption more predictable.

MEPs were responsive to diverse implications embedded in contents of the warnings. To begin with, the rightist MEPs favored the amendment making the warnings much more comprehensive than the Commission proposal (Warning Content 1), but were against the one introducing the word "addictive" for the smokeless tobacco. Likewise, the size of tobacco industry has a positive impact on MEPs' voting only on the first amendment. That is, MEPs from the member states with bigger tobacco industries actually supported it.

The smoking rate in MEPs' member states also explains the differences between the two amendments well. Whereas the variable did not influence MEPs' voting on more comprehensive warnings, it had a negative impact on their behavior in the votes for the other amendment. MEPs from the member states with large numbers of smokers tend to object to inserting the word "addictive" because they are more concerned about the smokers' displeasure.

In sum, MEPs address the partisan interests indicated by their ideological left-right positions as well as the salient constituency-based interests indicated by the strength of the tobacco industry and the number of smokers in their member states. Consideration of varying saliency of the issue for different societal groups drives MEPs to incorporate more acutely affected ones more seriously into the sets of constituency-based interests to represent. National parties also provide a channel to represent those interests compatible with their ideological positions.

\section{Conclusion}

What follows is a summary of the main findings of MEPs' policy seeking. First, despite institutional constraints on them, MEPs do pursue their policy interests in their

27) Martens, Debates of the European Parliament, Sittings of 13 June 2000. 
legislative voting. When they amend a proposed bill, they attempt to do so in favor of their policy interests. Second, MEPs' policy preferences are formed not only with partisanship based on the left-right ideology and EU integration but also constituency interests based on nationality. Nationality can be a significant factor in their behavior when the issue of the vote is relevant to national differences and salient for the electorates. Third, MEPs can be driven more by culture and lobbies from sectoral interests than by concern for public interests like public health. Notably, in the votes on the Tobacco Products Directive, MEPs from high smoking rate countries voted more in favor of low tobacco control. As awareness of smoking-caused harm is widely spread in the EU, the diversity of smoking rates over the EU member states should be attributed to different perceptions about smoking, rather than different levels of information on smoking. Then the influence of the smoking rate in MEPs' behavior shows that the attitude of the public in each member state is reflected at the EU policy making through MEPs.

There is another finding on the legislative voting in the EP that is worth mentioning. This article shows that MEPs are sensitive to the implications of individual amendments. This issue-sensitive voting amendment-by-amendment causes shifting coalitions of MEPs in pursuit of their interests. The shifting legislative coalitions over amendments then result in uncertainty of the final text of the whole bill. If MEPs form a legislative coalition with a concrete vision of the final text of the bill, they must agree on which amendments need to be adopted to make the ideal bill possible. This would lead to a stable coalition over the votes on amendments as well as on the whole bill. In other words, the same sets of MEPs would vote together over all the votes. This is not the case of the EP.

Overall, this research suggests the necessity of pursuing further research on the representational role played by the European Parliament in the EU policy-making process. Although the European Parliament has been known to champion those EUwide interests which are not pronounced either by the member state governments or by the Commission (e.g. consumer and environmental interests), such behavior is regarded as position-taking to promote its institutional status distinctive from other EU institutions rather than policy-seeking on behalf of their constituencies. My findings imply that constituencies do matter for MEPs even if bringing home their favored policies does not determine if MEPs or their parties win more votes at the next European election. To strengthen their raison d' etre as the representatives of the EU citizens, MEPs try to gain credits from their legislative activities. The emphasis on the constituency interests brings national interests back in the study of the European Parliament. How nationally-based groups are selected and represented in the name of constituencies by MEPs in broader policy areas is worth exploring. 


\section{REFERENCES}

Bitton, A., M. Neuman, and S. Glantz. "Tobacco Industry Attempts to Subvert European Union Tobacco Advertising Legislation." Center for Tobacco Control Research and Education, University of Califonia, San Francisco, 2002. http://repositories.cdlib.org/ctcre/tcpmi/EU2002.

Bouwen, P. "The Logic of Access to the European Parliament: Business Lobbying in the Committee on Economic and Monetary Affairs." Journal of Common Market Studies 42-3 (2004).

Budge, I., H.D. Klingemann, A. Volkens, J. Bara, and E. Tanenbaum. Mapping Policy Preferences. Estimates for Parties, Elections, and Governments 1945-1998. Oxford: Oxford University Press, 2001.

Carrubba, C. J., R. Clough, E. Montgomery, L. Murrah, R. Schambach, and M. Gabel. "Selection Bias in the Use of Roll Call Votes to Study Legislative Behavior." European Parliament Research Group Working Paper No. 11 (2003).

Cooper, A., and P. Kruzer. "Germany's Non-War against Smoking and the Tobacco Policy of the European Union." Unpublished manuscript (2002).

Cox, G., and M. McCubbins. "On the Decline of Party Voting in Congress." Legislative Studies Quarterly XVI-4 (1991).

Duina, F. and P. Kurzer. "Smoke in Your Eyes: The Struggle over Tobacco Control in the European Union." Journal of European Public Policy 11-1 (2004).

Dur, A. and D. de Bievre. "The Question of Interest Group Influence." Journal of Public Policy 27-1 (2007).

European Commission. "Attitudes of Europeans toward Tobacco." Special Eurobarometer. 239 (2006). http://ec.europa.eu/public_opinion/archives/ebs/ebs_239_en.pdf.

European Parliament. "European Parliament legislative resolution on the proposal for a European Parliament and Council directive on the approximation of the laws, regulations and administrative provisions of the Member States concerning the manufacture, presentation and sale of tobacco products, 2000". Official Journal of the European Communities C67, 1 March 2001.

Hausemer, P. "Participation and Political Competition in Committee Report Allocation. Under What Conditions Do MEPs Represent Their Constituents?" European Union Politics 7-4 (2006). 
Hix, S. "Parliamentary Behavior with Two Principals: Preferences, Parties and Voting in the European Parliament." American Journal of Political Science 46-3 (2002).

Hix, S., A. Noury, and G. Roland. "Power to the Parties: Cohesion and Competition in the European Parliament, 1979-2001?” British Journal of Political Science 34-4 (2005). ."Dimensions of Politics in the European Parliament." American Journal of Political Science 50-2 (2006).

Katz, R. and B. Wessels, eds. The European Parliament, National Parliaments and European Integration. Oxford: Oxford University Press, 1999.

Kreppel, A. "Rules, Ideology and Coalition Formation in the European Parliament: Past, Present and Future.” European Union Politics 1-3 (2000).

Marks, G. and M. Steenbergen. "Understanding Political Contestation in the European Union.” Comparative Political Studies 35-8 (2002).

Morelli, M. "Demand Competition and Policy Compromise in Legislative Bargaining." American Political Science Review 93-4 (1999).

Moravcsik, A. The Choice for Europe. Ithaca: Cornell University Press, 1998.

Neuhold, C. "Bridging the Gap? Members of the European Parliament between Action Constraints and (New) Demands." Unpublished manuscript (2002).

Princen, S. "Advocacy Coalitions and the Internationalization of Public Health Policies." Journal of Public Policy 27-1 (2007).

Raunio, T. "Beneficial Cooperation or Mutual Ignorance? Contacts between MEPs and National Parties," in B. Steunenberg and J. Thomassen, eds. The European Parliament. Moving toward Democracies in the EU. Oxford: Rowman and Littlefield 2002.

Ringe, N. "Policy Preference Formation in Legislative Politics: Structures, Actors, and Focal Point." American Journal of Political Science 49-4 (2005).

Scully, R. and D. Farrell. "MEPs as Representatives: Individual and Institutional Roles." Journal of Common Market Studies 41-2 (2003).

Steunenberg, B. and J. Thomassen, eds. The European Parliament. Moving toward Democracies in the EU. Oxford: Rowman and Littlefield, 2002.

Tsebelis, G. and A. Kalandrakis. "The European Parliament and Environmental Legislation," in B. Steunenberg and J. Thomassen, eds. The European Parliament. Moving toward Democracies in the EU. Oxford: Rowman and Littlefield, 2002.

Wlezien, C. "Patterns of Representation: Dynamics of Public Preferences and Policy." Journal of Politics 66-1 (2004). 